\title{
APLIKASI PEMBELAJARAN INTEGRAL BERBASIS WEB
}

\author{
Juwairiah, Retno Wulan Sari, Wilis Kaswidjanti \\ Jurusan Teknik Informatika UPN “Veteran" Yogyakarta \\ Jl. Babarsari 2 Tambakbayan 55281 Telp (0274) 485323
}

\begin{abstract}
Mathematics lessons, is one lesson that is not liked by the students. Hearing the words of mathematics, will only think of the word difficult by the students. This is because the medium of learning that there are still less attractive. The material is a material that is considered integral to the most difficult of lessons. Thus the need for an application that can be used to study the material with the pattern of applied learning and interesting. System development method used is waterfall method of analysis, design, programming, testing, and maintenance. This application uses the programming language PHP, MySql as database, Dreamweaver, Macromedia Flash for animation and Photoshop as graphic design. Web server used is Apache.

Keywords : Aplication,learning, Integral.

Pelajaran matematika, merupakan salah satu pelajaran yang tidak disukai oleh para siswa. Mendengar kata matematika, hanya akan terpikirkan kata susah oleh para siswa. Hal ini dikarenakan media pembelajaran yang ada masih kurang menarik. Materi integral merupakan materi yang dianggap paling sulit pada pelajaran. Sehingga perlu adanya sebuah aplikasi yang dapat digunakan untuk mempelajari materi tersebut dengan pola belajar aplikatif dan menarik.. Metode pengembangan sistem yang dipakai adalah metode waterfall yaitu analisis, perancangan, pemrograman, pengujian, dan pemeliharaan. Aplikasi ini menggunakan bahasa pemrograman PHP, MySql sebagai database, Dreamweaver, Macromedia Flash untuk animasi dan Photoshop sebagai desain grafisnya. Web Server yang digunakan adalah Apache.

Kata kunci : Aplikasi, Pembelajaran, Integral
\end{abstract}

\section{Pendahuluan}

Di negara Indonesia, matematika telah diajarkan kepada siswa sekolah dasar sampai perguruan tinggi. Setiap materi yang diajarkan sesuai dengan tingkat pendidikan sehingga semakin tinggi tingkat pendidikannya akan semakin kompleks tingkat kesulitan dan materi yang disampaikan. Munculnya ketakutan untuk mempelajari matematika disebabkan sugesti yang tertanam dalam benak seorang anak bahwa matematika itu sulit. Sugesti tersebut muncul dari orang-orang sekitar yang mengatakan matematika itu sulit dan lebih disebabkan pada pola pengajaran yang lebih menekankan pada hafalan dan kecepatan berhitung. Untuk mengatasi masalah tersebut guru sebagai penyampai ilmu harus mampu mengajarkan matematika lebih menarik dan mengembangkan daya nalar siswa.

Untuk mempermudah proses pembelajaran mata pelajaran matematika maka perlu dibuat sebuah alat bantu pembelajaran yang menarik menggunakan kemajuan teknologi komputer yang mempunyai kemampuan dalam membantu menyelesaikan permasalahan pada mata pelajaran tersebut. Solusi yang efektif tersebut dengan membuat suatu aplikasi pembelajaran matematika berbasis web, yang diharapkan dapat membantu para siswa mempelajari materi yang menggunakan gambar sebagai bahan ajarnya dan membuat soal dapat lebih mudah dimengerti.

\section{Rumusan Masalah}

Berdasarkan latar belakang di atas, maka dapat dibuat rumusan masalah, yaitu : "Bagaimana membuat suatu aplikasi pembelajaran matematika berbasis web ?"

\section{Batasan Masalah}

Untuk memberikan ruang lingkup yang jelas terhadap suatu objek penelitian, maka dibuat batasan-batasan masalah dalam pembuatan sistem pembelajaran ini :

1. Dalam pelajaran matematika ada banyak materi yang disampaikan, namun aplikasi ini hanya mempelajari implementasi integral untuk mencari luas daerah dan volume benda putar. 
2. Pada aplikasi pembelajaran ini memberikan informasi berupa materi, visualisasi, soal latihan dan tes.

3. Aplikasi pembelajaran ini menggunakan multimedia berupa teks, suara dan gambar

\section{Metodologi Pengembangan Sistem}

Metode yang digunakan dalam pengembangan sistem atau perangkat lunak yaitu metode waterfall (siklus air terjun) yang meliputi : rekayasa dan permodelan sistem, analisis kebutuhan, perancangan sistem (design), pemrograman (codingi), pengujian (testing) dan pemeliharaan (maintenance). Namun pada pada sistem ini hanya sampai pada tahap kelima yaitu pengujian.

\section{Analisis dan Perancangan}

Berdasarkan masalah pada latar belakang, maka diperlukan spesifikasi kebutuhan yang berhubungan dengan kemampuan aplikasi pembelajaran yang akan dibuat. Pengguna aplikasi ini ada 2 macam, yaitu umum dan admin. Analisis sistem ini memuat 3 hal, yaitu:

1. Analisis masukan (input)

User (umum) memberi masukan dalam menu tes berupa jawaban dari soal yang diberikan. Tipe jawaban berupa pilihan ganda, sehingga user (umum) hanya memilih salah satu jawaban yang sudah disediakan. Admin dapat melakukan input data teori integral, data latihan, data tes, dan. data pembahasan tes.

2. Analisis Proses

Untuk user (umum) Aplikasi akan memproses jawaban dan menghitung berapa nilai yang benar. Untuk admin, dapat melakukan olah data (tambah, hapus, edit) untuk data teori integral, data latihan, data tes, dan data pembahasan tes.

3. Analisis Keluaran (output)

Untuk user (umum), aplikasi akan menampilkan tentang teori integral, data latihan, simulasi penggambaran grafik fungsi kuadrat, data tes, data pembahasan tes, dan hasil nilai tes.

\section{Perancangan Proses}

\section{Data Flow Diagram (DFD) Level 0}

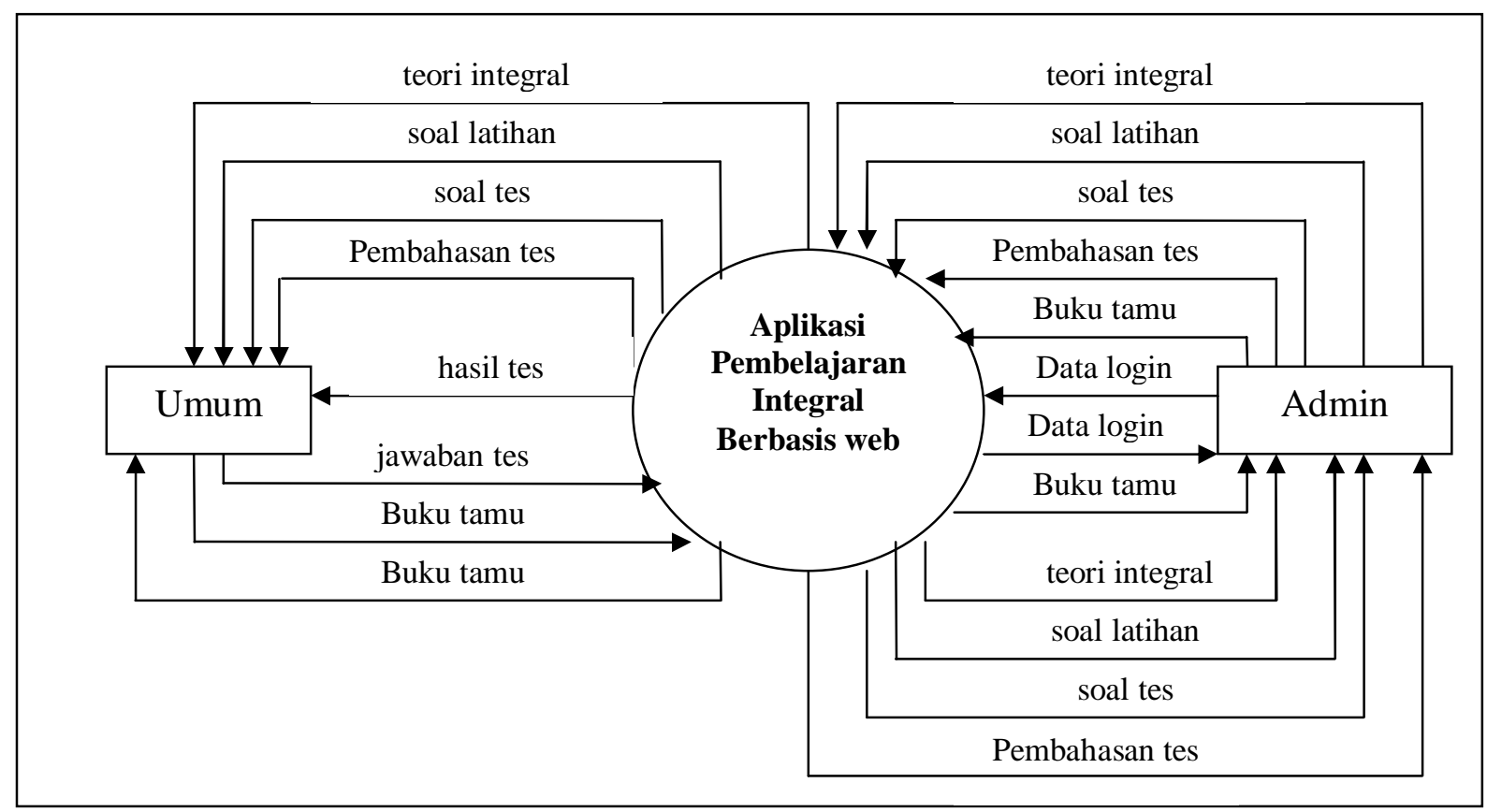

Gambar 1. DFD Level 0

\section{Implementasi}

Aplikasi pembelajaran integral berbasi web ini terbagi menjadi dua tampilan antarmuka yaitu antar muka untuk umum dan antarmuka untuk admin. Antarmuka untuk user mempunyai tujuh halaman antarmuka yaitu halaman home, halaman teori integral, halaman simulasi, halaman latihan, halaman tes, halaman pesan dan halaman about me. Sedangkan antarmuka untuk admin mempunyai tujuh halaman antarmuka yaitu halaman home admin, halaman olah 
data teori, halaman olah data latihan, halaman olah data tes, halaman olah data pembahasan tes, halaman olah data pesan dan halaman ubah password admin.

\section{Halaman menu utama}

Pada aplikasi ini terdapat halaman menu utama yang merupakan halaman yang pertama kali dibuka oleh umum. Pada halaman menu utama akan ditampilkan pilihan menu yang tersedia dalam sistem, yaitu : teori integral, latihan, tes, pesan dan about me. User(umum) dapat memilih dan membuka menu-menu tersebut sesuai yang diinginkan. Pada menu utama juga terdapat tombol admin yang berfungsi bagi admin untuk masuk ke halaman admin, dalam hal ini user biasa tidak dapat masuk ke halaman admin.

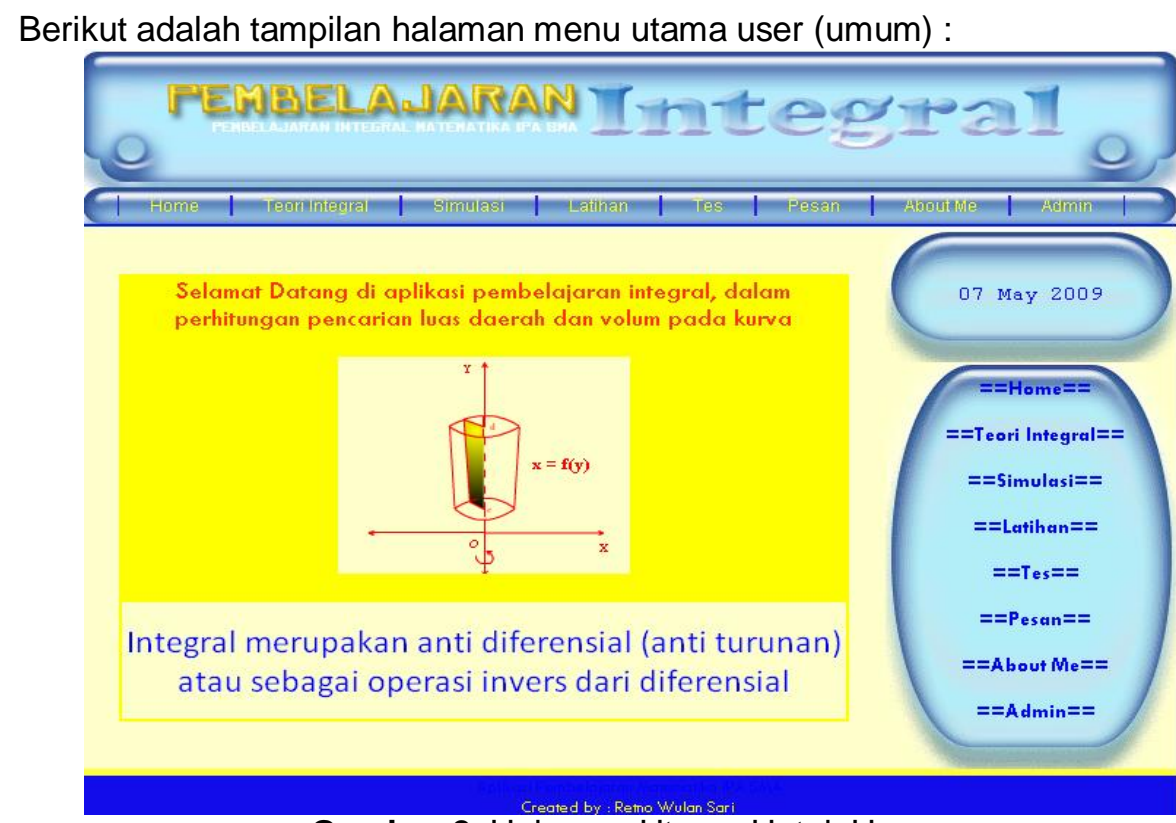

\section{Halaman teori integral}

\section{Gambar 2. Halaman Utama Untuk Umum}

Sebelum user masuk ke halaman teori, user dapat memilih teori yang ingin dibuka yaitu pada halaman pilih teori. Pada halaman ini, terdapat penggalan-penggalan pengertian dari masing-masing teori. Terdapat empat halaman teori yang dapat dipilih yaitu halaman teori dasar integral tak tentu, halaman teori dasar integral tertentu, halaman integral pencarian luas daerah dan halaman integral pencarian volume benda putar. Berikut adalah tampilan halaman pilih teori

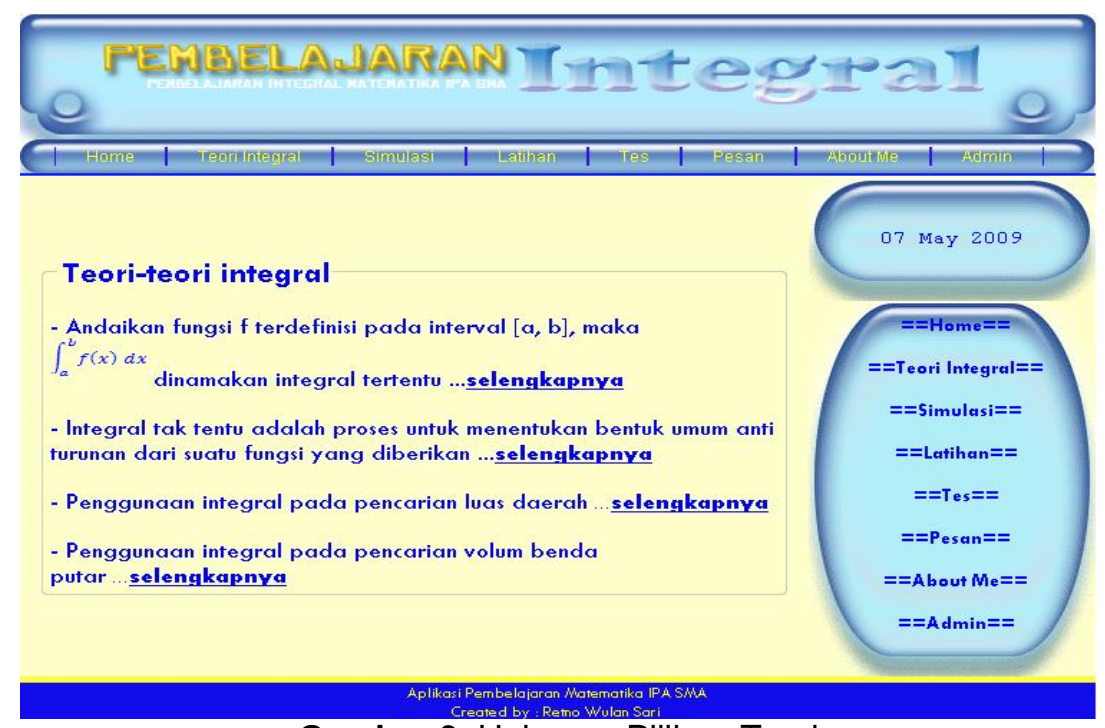

Gambar 3. Halaman Pilihan Teori 


\section{Halaman Simulasi}

Pada halaman simulasi, user dapat mensimulasikan persamaan kurva menjadi sebuah gambar kurva. User dapat menuliskan persamaan dengan cara mengisikan angka-angka pada persamaan yang telah tersedia dengan menekan tombol angka. Kemudian pada simulasi ini user juga dapat melihat titik yang dilalui kurva dengan menekan tombol titik satu hingga titik lima. Kemudian untuk melihat hasilnya user dapat menekan tombol gambar, sehingga kurva akan terbentuk pada bidang koordinat yang telah tersedia. Pada halaman simulasi ini terdapat dua halaman simulasi yaitu halaman simulasi persamaan sumbu $X$ dan kurva simulasi persamaan sumbu Y. Berikut adalah tampilan halaman simulasi persamaan sumbu $\mathrm{X}$.

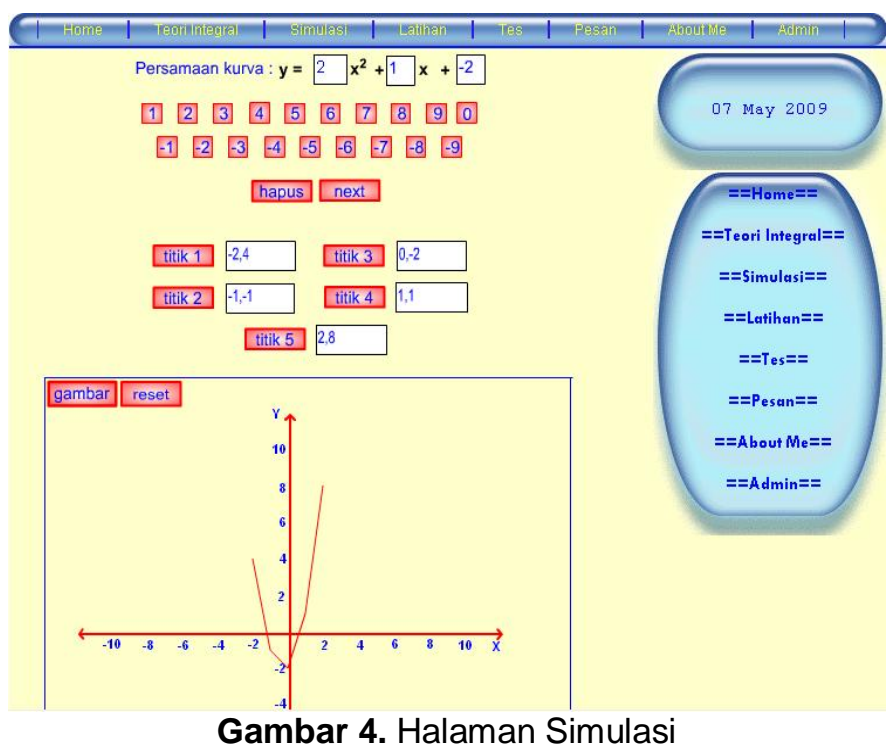

\section{Halaman latihan}

Gambar 4. Halaman Simulasi

Sebelum masuk ke halaman latihan, user dipersilahkan untuk memilih latihan integral dalam pencarian luas daerah atau latihan integral dalam pencarian volume benda putar. Pada halaman latihan luas atau volume terdiri atas soal latihan, gambar kurva, dan pembahasan latihan. Setiap satu halaman latihan terdiri dari satu soal sehingga user apabila ingin melihat soal latihan selanjutnya dapat menekan next atau user dapat menekan prev untuk melihat soal sebelumnya. User juga dapat menekan nomor pilihan halaman latihan soal yang ada. Berikut adalah tampilan halaman latihan integral luas daerah

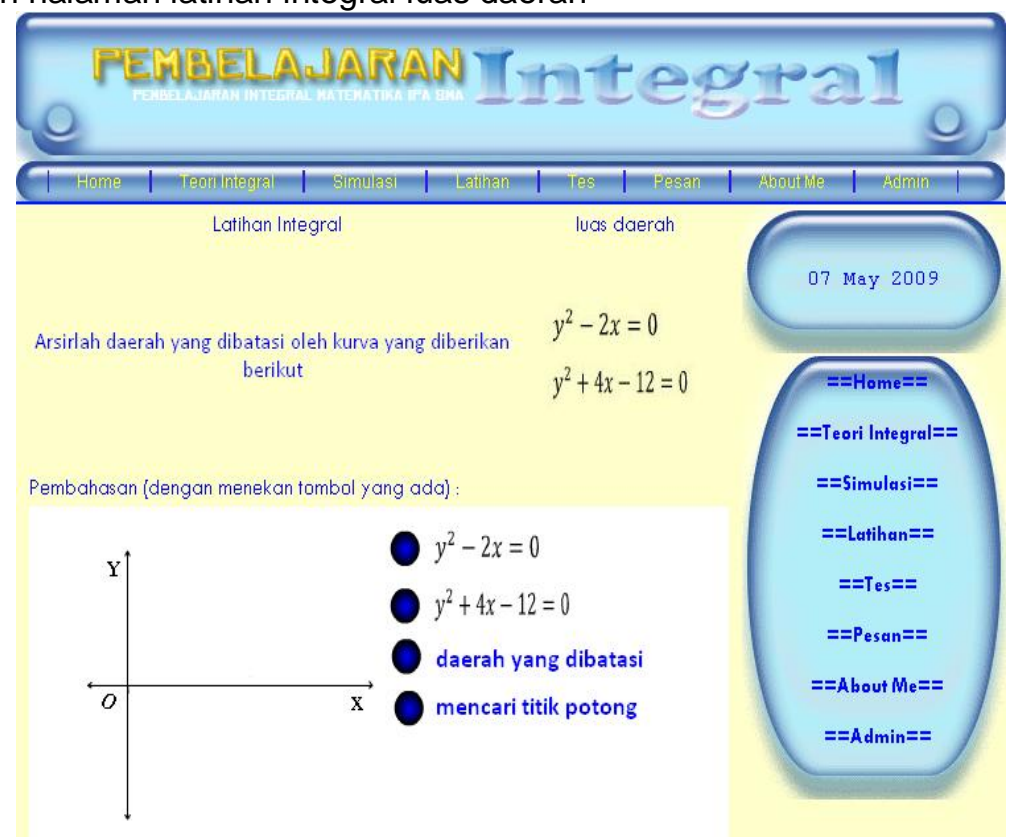

Gambar 5. Halaman Latihan luas 
Berikut adalah tampilan halaman latihan integral volume benda putar

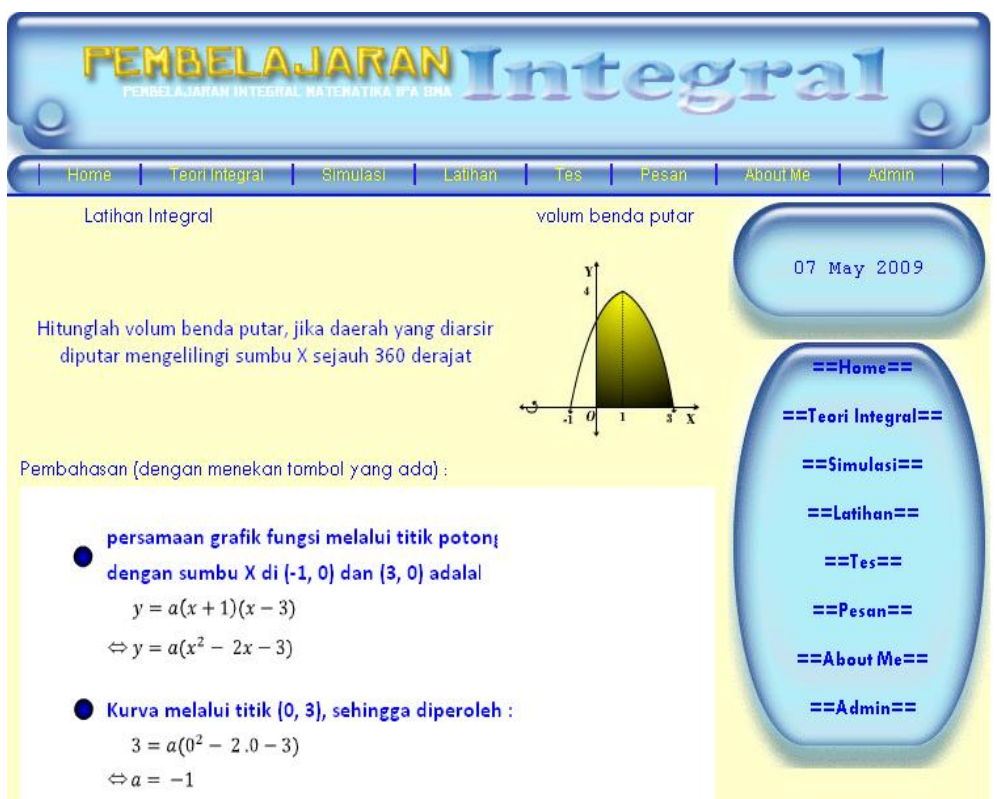

\section{Halaman tes}

\section{Gambar 6. Halaman Latihan Volume}

Sebelum user masuk ke halaman tes, user masuk ke halaman pilihan tes. Pada halaman pilihan tes, user di minta untuk memilih jumlah soal yang akan dikerjakan. Pada halaman tes, terdapat lima soal pilihan ganda yang dapat dikerjakan oleh user. Satu soal terdiri dari soal tes, gambar kurva dan empat pilihan jawaban. Setelah user selesai, maka user dapat menekan tombol hasil.

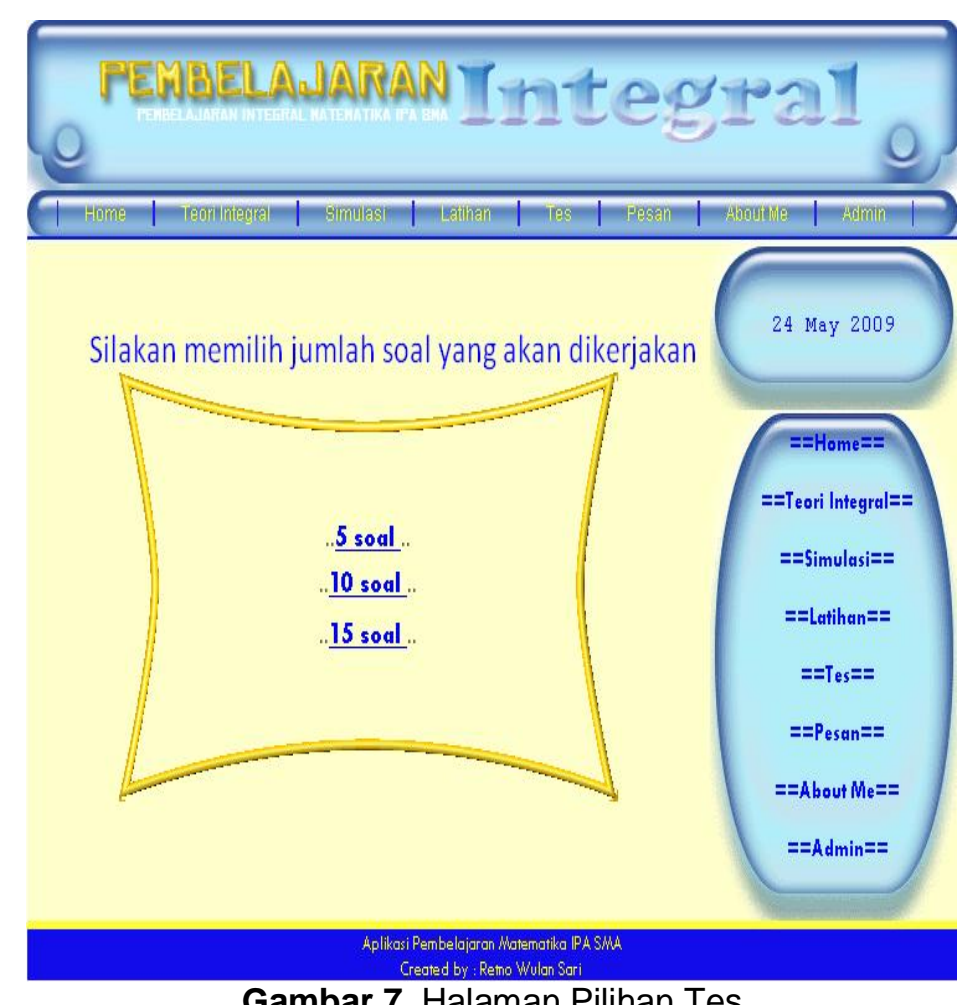

Gambar 7. Halaman Pilihan Tes

Berikut adalah tampilan halaman tes integral, dimana apabila user memilih jumlah soal lima maka soal yang akan tampil sebanyak lima soal. Begitu pula dengan pilihan soal sepuluh dan lima belas 


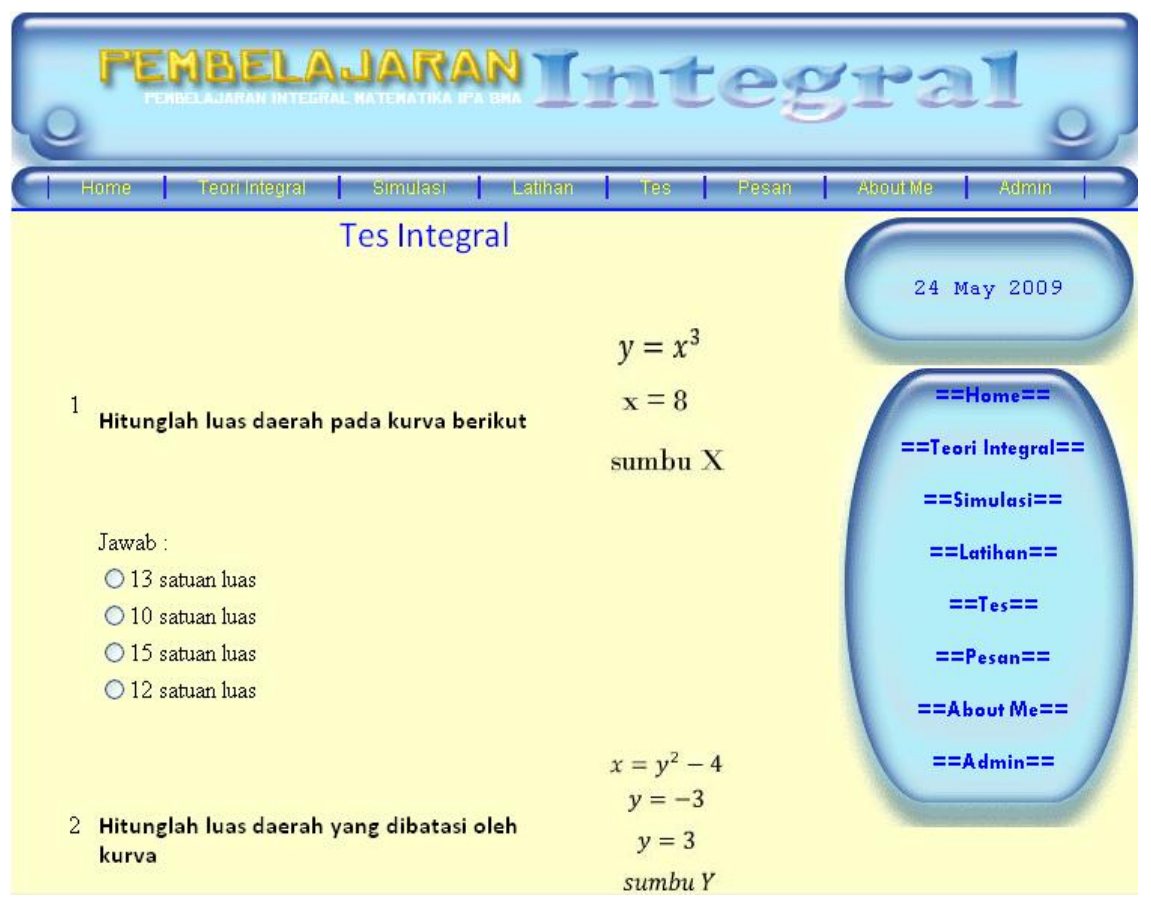

Gambar 8. Halaman Soal Tes

Berikut adalah tampilan hasil dari pengerjaan soal-soal tes. Pada halaman ini terdapat nilai yang diperoleh dan terdapat pilihan bagi user yaitu mengerjakan soal-soal tes kembali atau ingin melihat pembahasan dari soal tes yang telah dikerjakan.

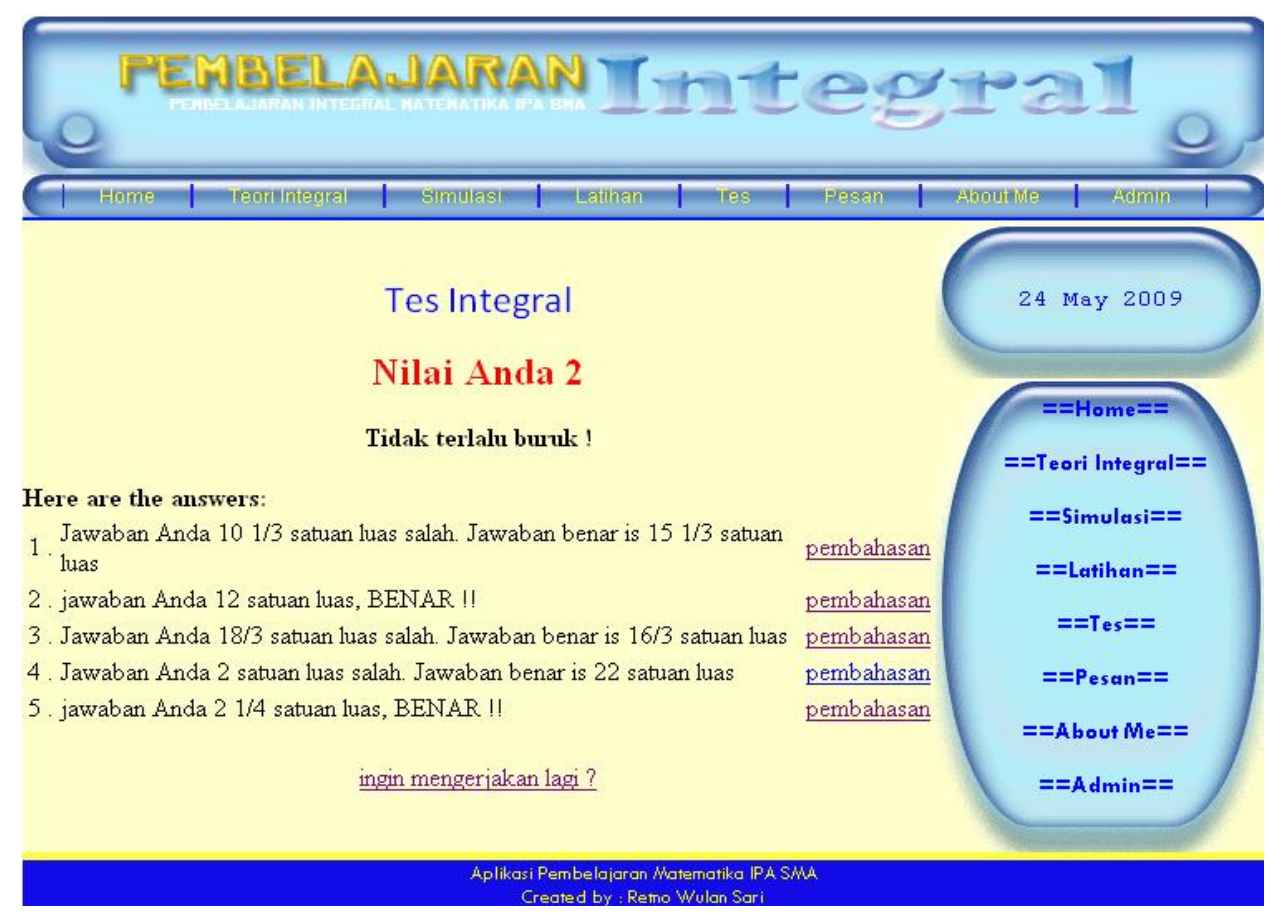

Gambar 9. Halaman Nilai Tes

Berikut adalah tampilan halaman pembahasan tes 


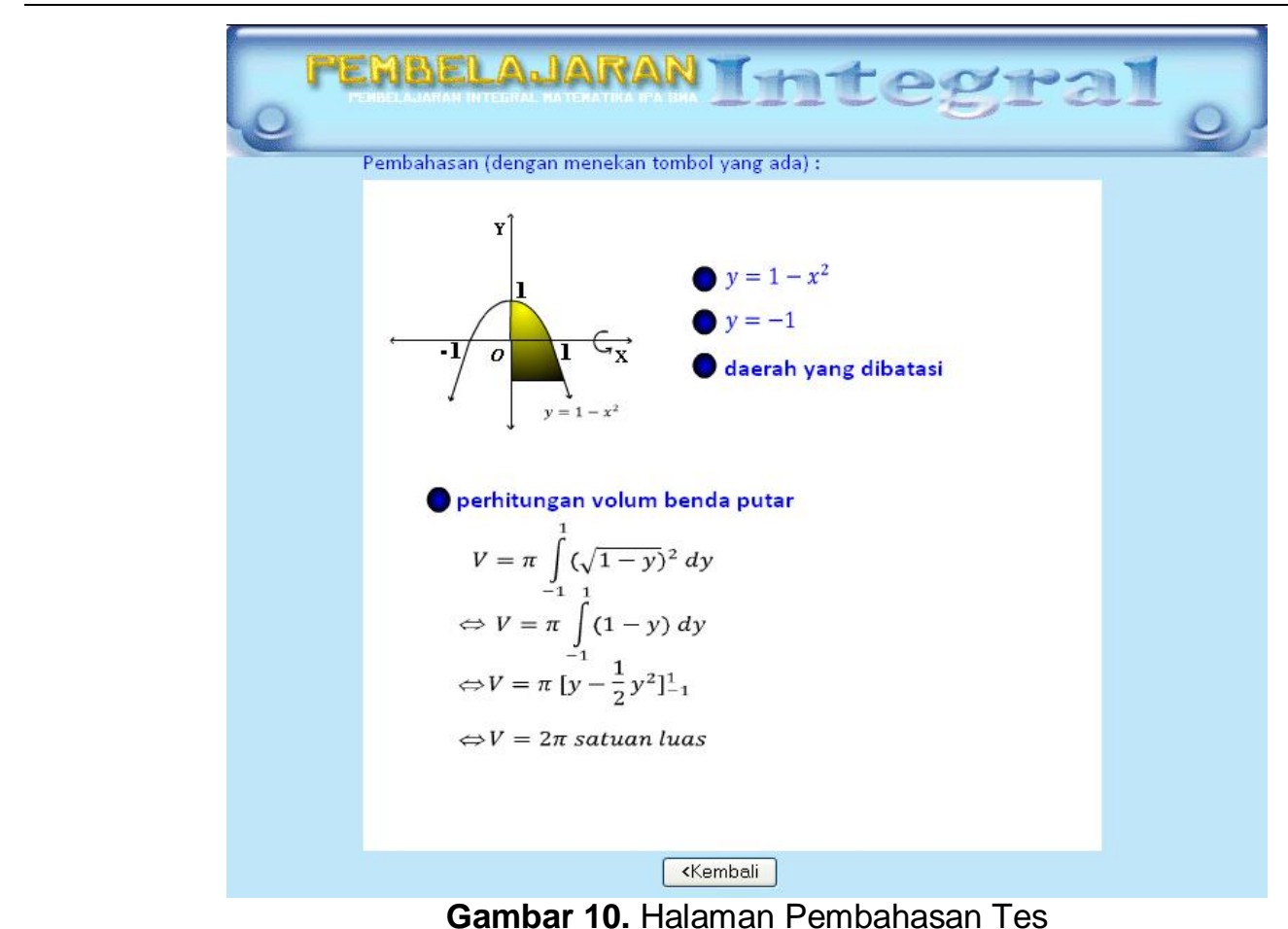

\section{Halaman Utama Admin}

\section{Gambar 10. Halaman Pembahasan Tes}

Pada halaman menu utama admin merupakan halaman yang pertama kali dibuka oleh admin ketika pertama kali masuk ke halaman admin. Pada halaman menu utama admin akan ditampilkan pilihan menu yang tersedia dalam halaman admin yaitu : teori integral, latihan, tes, pembahasan tes dan halaman ubah password. Admin dapat memilih dan membuka menumenu tersebut sesuai yang diinginkan untuk mengolah data. Pada halaman kiri halaman admin juga terdapat menu yang berfungsi sama dengan pilihan menu. Pada halaman admin terdapat menu logout, yang berfungsi untuk keluar dari halaman admin dan langsung menuju ke halaman utama user.

Berikut adalah tampilan halaman utama dari halaman admin

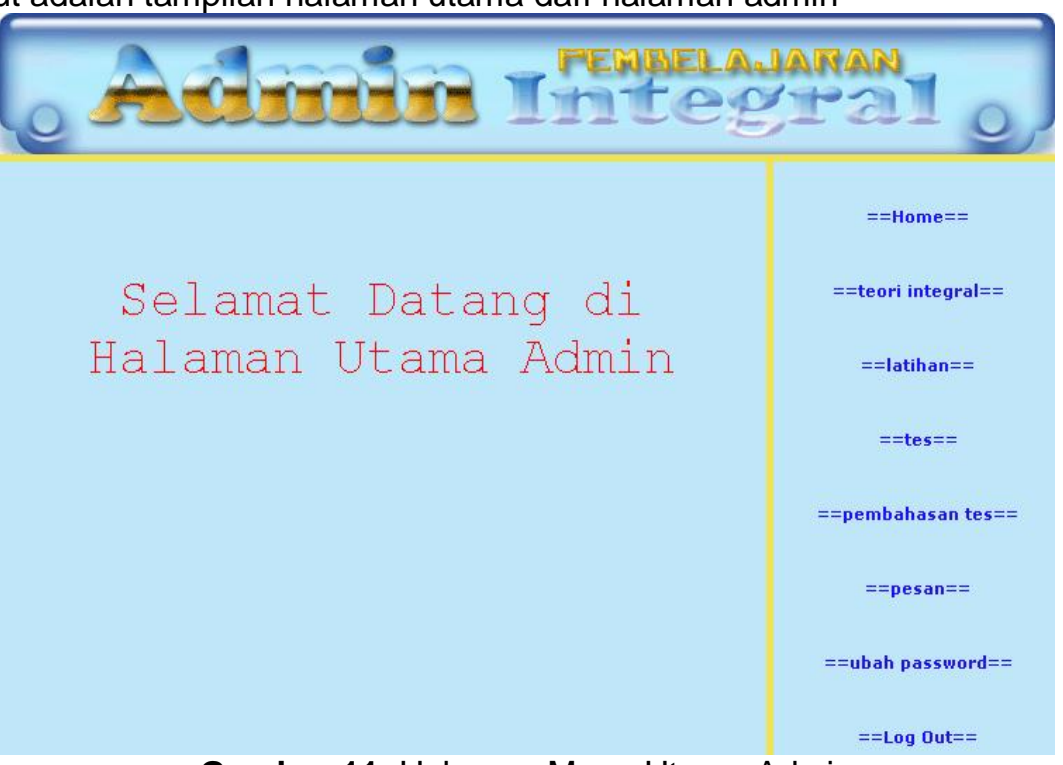

\section{Halaman Olah Data Teori}

Gambar 11. Halaman Menu Utama Admin

Pada halaman olah data teori, terdapat tabel yang berisi teori integral untuk pencarian luas daerah dan teori integral untuk pencarian volume benda putar. Admin dapat menambah, menghapus dan mengubah data teori integral. Pada halaman tambah data teori, data yang harus dimasukkan adalah tipe teori yaitu luas atau volume, teori integral baik teori untuk implementasi pencarian luas daerah maupun teori untuk implementasi pencarian volumee 
benda putar, suara, gambar teori yaitu gambar kurva yang berupa file .swf, rumus yang berupa file .jpeg. Berikut adalah tampilan halaman tambah teori integral

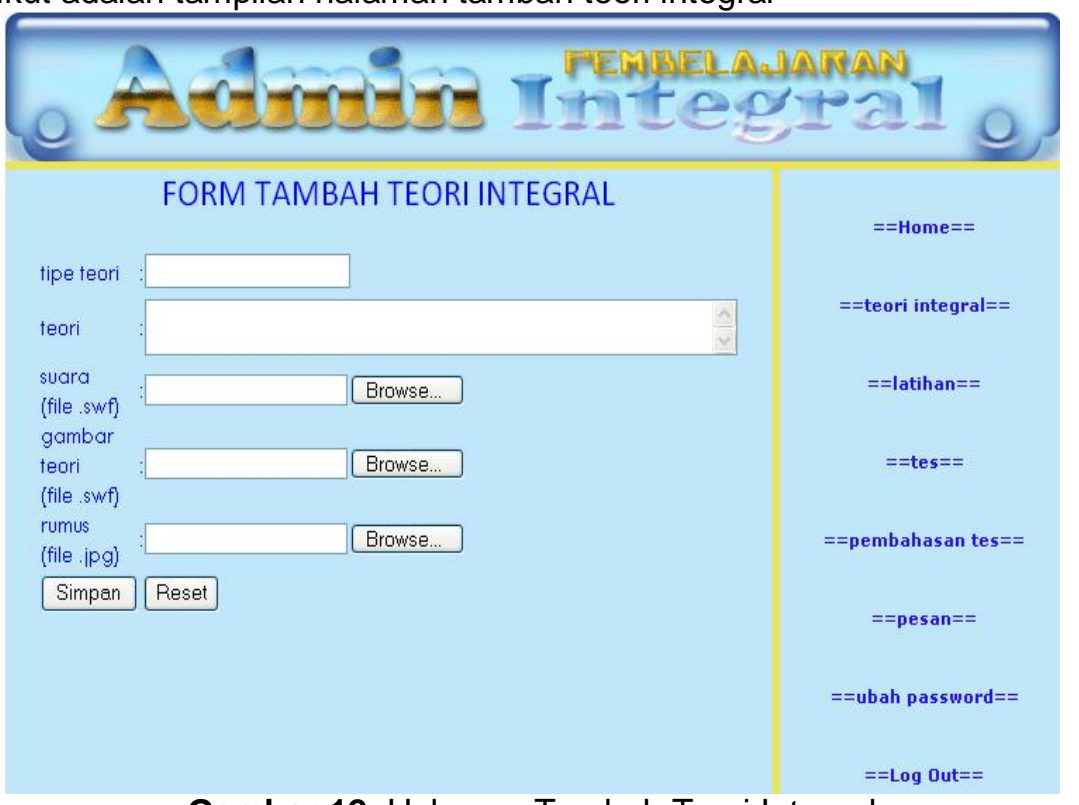

\section{Halaman Olah Data Latihan}

Gambar 12. Halaman Tambah Teori Integral

Pada halaman olah data latihan,, terdapat tabel yang berisi latihan integral untuk pencarian luas daerah dan latihan integral untuk pencarian volume benda putar. Admin dapat menambah, menghapus dan mengubah data latihan. Berikut adalah tampilan halaman tambah data latihan

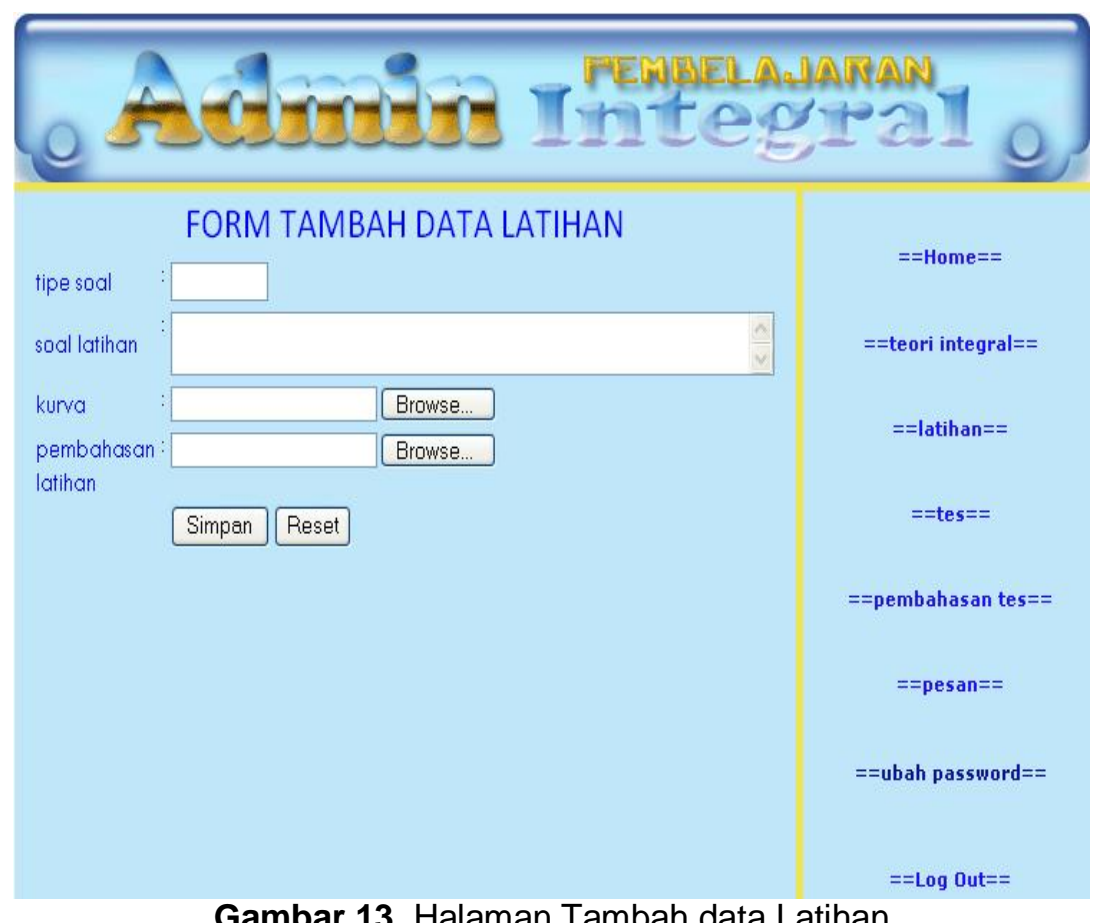

\section{Halaman Olah Data Tes}

Gambar 13. Halaman Tambah data Latihan

Pada halaman olah data tes,, terdapat tabel yang berisi soal tes integral untuk pencarian luas daerah dan soal tes integral untuk pencarian volume benda putar. Admin dapat menambah, menghapus dan mengubah data tes. Pada halaman ini data yang tercantum hanyalah data paket soal, nomor soal dan soal tes. Apabila ingin melihat keseluruhan data maka admin dapat menekan data soal tes karena terhubung dengan halaman hasil olah data integral. 
Pada halaman tambah data tes, data yang harus dimasukkan adalah, id tes, soal tes baik berupa soal tes untuk implementasi pencarian luas daerah maupun soal tes untuk implementasi pencarian volumee benda putar, kurva yaitu gambar kurva yang berupa file .jpeg, jawaban a, jawaban b, jawaban c, jawaban d, jawaban benar. Berikut adalah tampilan halaman tambah data tes

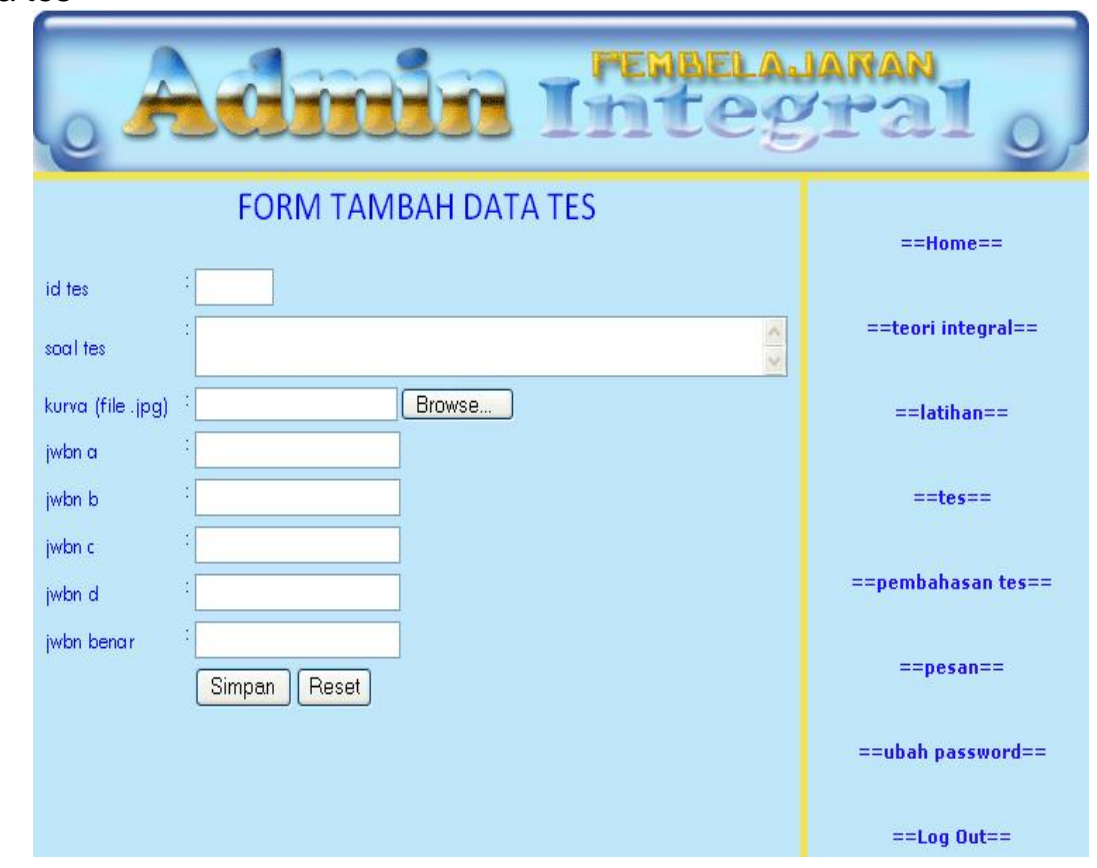

Gambar 14. Halaman Tambah Data Tes

\section{Halaman Data Pembahasan Tes}

Pada halaman olah data pembahasan tes, terdapat tabel yang berisi id tes dan pembahasan tes. Admin dapat menambah, menghapus dan mengubah data pembahasan tes. Pada halaman tambah data pembahasan tes, data yang harus dimasukkan adalah nomor soal id tes, dan pembahasan tes. Berikut adalah tampilan halaman tambah data tes

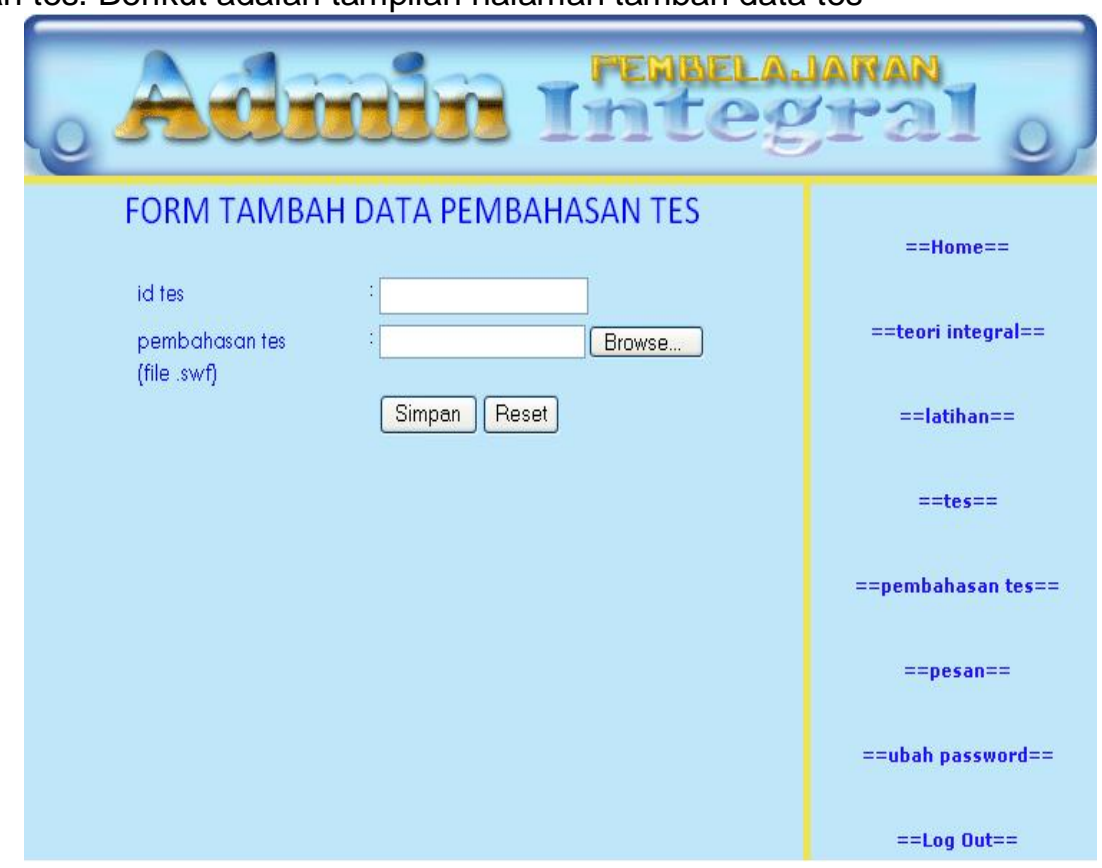

Gambar 15. Halaman Tambah Data Pembahasan Tes 


\section{Kesimpulan dan Saran}

Telah dapat dirancang dan dibangun sebuah aplikasi pembelajaran integral berbasis web. Aplikasi ini dapat menjadi alat untuk belajar matematika khususnya materi integral khususnya dalam pencarian luas daerah dan volume benda putar pada kurva.

Aplikasi ini dapat dikembangkan oleh peneliti selanjutnya dengan menggunakan aplikasi Moodle yang merupakan salah satu aplikasi dari Course Management System (CMS). Moodle dapat merubah sebuah media pembelajaran ke dalam bentuk web. Moodle juga dapat membuat materi pembelajaran, kuis, jurnal elektronik dan lain-lain.

\section{DAFTAR PUSTAKA}

Fathansyah, 2007, Basis Data, Penerbit Informatika, Bandung.

Kurniawan, Budi, 2008, Desain Web Praktis Dengan CSS, PT. Elex Media Komputindo, Jakarta Kusrianto, Adi, 2006, Panduan Lengkap Memakai Macromedia Flash Professional 8, PT Elex Media Komputindo, Jakarta

Pressman R.S, 2002, Rekayasa Perangkat Lunak, Penerbit ANDI, Yogyakarta

Purwasasmita, Mubiar, 2000, Konsep Teknologi, Institut Teknologi Bandung, Bandung

Rickyanto, Isak, 2002, Belajar sendiri JSP. PT Elex Media Komputindo, Jakarta

Sutarman, 2007, Membangun Aplikasi Web dengan PHP \& MySQL, Edisi 2, Graha IImu, Yogyakarta

Suyanto, M, 2003, Multimedia Untuk Meningkatkan Keunggulan Bersaing, Penerbit ANDI, Yogyakarta

Syahputra, Andry, 2003, Apache Web Server, ANDI Yogyakarta, Yogyakarta

Tampomas, Husein,1999, Seribu Pena Matematika SMU Kelas 3, Jilid 3, Erlangga, Jakarta 